Reprinted with permission from: Weed Science. 2000, Vol. 48:2:255-265.

Published and copyrighted by: Weed Science Society of America. http://www.wssa.net

\title{
Invasive weeds in rangelands: Species, impacts, and management
}

\author{
JOSEPH M. DITOMASO \\ Weed Science Program, Department of Vegetable Crops, University of California, Davis, CA 95616. \\ ditomaso@vegmail.ucdavis.edu.
}

\begin{abstract}
:
Rangeland and pastures comprise about $42 \%$ of the total land area of the United States. About three-quarters of all domestic livestock depend upon grazing lands for survival. Many ranges have had domestic stock grazing for more than 100 years and, as a result, the plant composition has changed greatly from the original ecosystems. Western rangelands previously dominated by perennial bunchgrasses have been converted, primarily through overgrazing, to annual grasslands that are susceptible to invasion by introduced dicots. Today there are more than 300 rangeland weeds in the United States. Some of the most problematic include Bromus tectorum, Euphorbia esula, Centaurea solstitialis, C. diffusa, C. maculosa, and a number of other Centaurea species. In total, weeds in rangeland cause an estimated loss of $\$ 2$ billion annually in the United States, which is more than all other pests combined. They impact the livestock industry by lowering yield and quality of forage, interfering with grazing, poisoning animals, increasing costs of managing and producing livestock, and reducing land value. They also impact wildlife habitat and forage, deplete soil and water resources, and reduce plant and animal diversity. Numerous mechanical and cultural control options have been developed to manage noxious rangeland weeds, including mowing, prescribed burning, timely grazing, and perennial grass reseeding or interseeding. In addition, several herbicides are registered for use on rangelands and most biological control programs focus on noxious rangeland weed control. Successful management of noxious weeds on rangeland will require the development of a long-term strategic plan incorporating prevention programs, education materials and activities, and economical and sustainable multi-year integrated approaches that improve degraded rangeland communities, enhance the utility of the ecosystem, and prevent reinvasion or encroachment by other noxious weed species.
\end{abstract}




\section{Nomenclature:}

Bromus tectorum L. BROTE, downy brome; Centaurea diffusa Lam. CENDI, diffuse knapweed; Centaurea maculosa Lam. CENMA, spotted knapweed; Centaurea solstitialis L. CENSO, yellow starthistle; Euphorbia esula L. EPHES, leafy spurge.

\section{Keywords:}

Grassland, IPM, noxious weed, prevention, BROTE, CENDI, CENMA, CENSO, EPHES.

An estimated 400 million ha or $42 \%$ of the total land area of the United States is used for pasture and grazing (Bovey 1987). Most wildlife and livestock depend upon rangelands for survival. In the United States, rangeland is represented by a variety of ecosystems, including desert and rich alluvial valleys, coastal and inland foothills, high mountain meadows, and inland plains. Domestic livestock, particularly Bos (cattle), Ovis (sheep) and Equus (horses), have grazed many of these ranges for nearly 200 years. As a result, the plant composition has changed greatly from the original ecosystems (Murphy 1986).

A number of species can cause significant problems on rangelands (Table 1). The vast majority of these weeds have been introduced from other continents. However, management practices, particularly fire suppression or overgrazing, have increased the proportion of some native species. These natives can reduce overall forage quality or quantity (e.g., Juniperus spp., Artemisia tridentata, and Gutierrezia spp.) or poison livestock (e.g., Delphinium spp., Astragalus spp., and Amsinckia menziesii var. intermedia). No particular life cycle is typical to noxious weeds of rangeland. Noxious range weeds can be annuals (e.g., Centaurea solstitialis, Crupina vulgaris, Bromus tectorum), biennials (e.g., Carduus

nutans, Conium maculatum, Onopordum acanthium), long-lived herbaceous perennials (e.g., Convolvulus arvensis, Centaurea maculosa, Cirsium arvense), shrubs (e.g., Gutierrezia spp., Artemisia tridentata), or trees (e.g., Juniperus spp., Prosopis glandulosa). Although these species are represented by several plant families, the largest number of noxious species belong to the Asteraceae (sunflower) family.

Of the species listed in Table 1, perhaps the most widespread and troublesome are $C$ solstitialis, B. tectorum, Euphorbia esula, and a number of Centaurea species, particularly $C$. diffusa and C. maculosa. Each of these species has infested more than 1 million ha in the western states (Table 2). These and other invasive rangeland weeds often infest annual communities dominated by introduced grasses (Roché and Roché 1991).

Species within the genus Centaurea probably represent the most significant threat to rangeland and pasture management in the northern intermountain region. They are highly competitive in a wide range of habitats (Roché et al. 1986). At least 15 introduced species of Centaurea are considered weedy in western rangeland (Roché and Roché 1991). Most are low in palatability, and C. solstitialis and Acroptilon repens are toxic to horses (Kingsbury 1964; Panter 1991). These species not only readily occupy disturbed sites 
previously dominated by annual grasses, but also invade relatively undisturbed perennial native plant communities.

\section{Table 1. Major rangeland weeds in the western United States.}

\begin{tabular}{|c|c|c|c|c|}
\hline Family & Species & Common name & Life cycle & $\begin{array}{l}\text { Native }(\mathrm{N}) \text { or } \\
\text { Introduced }(\mathrm{I})\end{array}$ \\
\hline Cupressaceae & Juniperus spp. & juniper & woody perennial & $\mathrm{N}$ \\
\hline Apiaceae & Conium maculmum $\mathrm{L}$. & poison hemlock & biennial & I \\
\hline \multirow[t]{19}{*}{ Asteraceae } & Acroptilon repens (L.) DC. & Russian knapweed & herbaceous perennial & I \\
\hline & Artemisia tridentata Nutt. & big sagebrush & woody perennial & $\mathrm{N}$ \\
\hline & Carduus nutans L. & musk thistle & winter annual or biennial & I \\
\hline & Centaurea diffusa Lam. & diffuse knapweed & annual to perennial & I \\
\hline & Centaurea maculosa Lam. & spotted knapweed & herbaceous perennial & I \\
\hline & Centaurea solstitialis $\mathrm{L}$. & yellow starthistle & winter annual & I \\
\hline & Centaurea squarrosa Willd. & squarrose knapweed & annual, biennial, or perennial & I \\
\hline & Centaurea jacea $\mathrm{L}$ & meadow knapweed & annual, biennial, or perennial & I \\
\hline & Centaurea calcitrapa $\mathrm{L}$. & purple starthistle & annual, biennial, or perennial & I \\
\hline & Centaurea melitensis $\mathrm{L}$. & Malta starthistle & annual & I \\
\hline & Cirsium vulgare (Savi) Ten. & bull thistle & biennial or perennial & I \\
\hline & Cirsium arvense (L.) Scop. & Canada thistle & biennial or perennial & I \\
\hline & Chondrilla juncea L. & rush skeletonweed & herbaceous perennial & I \\
\hline & Chrysothamnus spp. & rabbitbrush & woody perennial & $\mathrm{N}$ \\
\hline & Crupina vulgaris Cass. & common crupina & winter annual & I \\
\hline & Gutierrezia spp. & snakeweed & woody perennial & $\mathrm{N}$ \\
\hline & Hieracium spp. & hawkweed & herbaceous perennial & $\mathrm{I}$ \\
\hline & Onopordum acanthium $\mathrm{L}$. & Scotch thistle & biennial & I \\
\hline & Senecio Jacobaea L. & tansy ragwort & biennial or perennial & I \\
\hline \multirow[t]{2}{*}{ Boraginaccae } & $\begin{array}{l}\text { Amsinckia menziesii } \quad \text { var, } \\
\text { intermedia } \quad \text { (Fischer } \quad \& \\
\text { C. Meyer) Ganders }\end{array}$ & coast fiddleback & winter annual & $\mathrm{N}$ \\
\hline & Cynoglossum officinak L. & houndstongue & biennial & I \\
\hline \multirow[t]{3}{*}{ Brassicaceae } & Cardaria draba (L.) Desv. & hoary cress & perennial & I \\
\hline & Isatis tinctoria $\mathrm{L}$. & dyer's woad & biennial or perennial & I \\
\hline & Lepidium latifolium L. & perennial pepperweed & perennial & I \\
\hline Convolvulaceae & Convolvulus arvensis L. & field bindweed & herbaceous perennial & I \\
\hline Euphorbiaceae & Euphorbia esula L. & leafy spurge & herbaceous perennial & I \\
\hline \multirow[t]{2}{*}{ Fabaceae } & Astragalus spp. & locoweeds & annual to perennial & $\mathrm{N}$ \\
\hline & Prosopis glandulosa Torrey & honey mesquite & woody perennial & $\mathrm{N}$ \\
\hline Hypericaccae & Hypericum perforatum L. & common St. Johnswort & herbaceous perennial & I \\
\hline \multirow[t]{3}{*}{ Poaceae } & Aegilops cylindrica Host & jointed goatgrass & winter annual & I \\
\hline & Bromus tectorum $\mathrm{L}$. & downy brome & winter annual & I \\
\hline & $\begin{array}{l}\text { Taeniatherum caputmedusae } 1 \\
\text { (L.) Nevski }\end{array}$ & medusahead & winter annual & I \\
\hline Ranunculaceae & Delphinium spp. & larkspurs & annual to perennial & $\mathrm{N}$ \\
\hline Rosaceae & Potentilla recta $\mathrm{L}$. & sulfur cinquefoil & herbaceous perennial & I \\
\hline Scrophulariaceae & Linaria spp. & toadflax & herbaceous perennial & I \\
\hline
\end{tabular}

Euphorbia esula currently infests more than 1.1 million ha in the northern Great Plains and intermountain West. Its rate of spread has increased rapidly, doubling every 10 years for the past 30 years (Wallace et al. 1992). E. esula, Centaurea spp., and many other noxious range weeds continue to spread at an estimated rate of 8 to $14 \%$ per year (Whitson 1998).

B. tectorum is the most dominant noxious weed species in the intermountain West, infesting more than 40 million ha (Rosentreter 1994). It is a problem not only of rangeland 
but also of winter crops, hayfields, pastures, grass seed fields, and other crops (Morrow and Stahlman 1984). After its introduction around 1861, B. tectorum spread rapidly and widely in the early 1900s, particularly into overgrazed Artemisia spp. rangeland (Billings 1994). Though it is used to some degree as a livestock forage, in some years it only provides $10 \%$ of the productivity of the perennial species it replaced (McHenry and Murphy 1985). Furthermore, the abundance of fuel from dry B. tectorum in the summer has led to a reduction in the Artemisia steppe fire interval from 60 to 110 years before its introduction to less than five years today (Whisenant 1990). As a result, the native shrub species have declined dramatically in these burned areas (Billings 1994).

\section{Factors contributing to the spread of noxious rangeland weeds}

Before the introduction of annual grasses, perennial bunchgrasses were the primary native species in rangelands west of the Rocky Mountains. These included Festuca idahoensis, Poa secunda, Festuca kingii, Pseudoroegneria spicata, Leymus cinereus, Elymus elymoides, Achnatherum hymenoides, Hesperostipa comata, and Achnatherum occidentalis (Billings 1994). These perennial grass species do not have high seedling vigor nor do they readily recover from grazing (Callihan and Evans 1991). With the introduction of exotic annual grasses and livestock, native perennial grass plants were overgrazed and quickly replaced by introduced winter annual grasses (Young and Longland 1996). In some areas, overgrazing of perennial grasses selected for unpalatable native woody or poisonous species (DeLoach 1991). Suppression of periodic wildfires also increased shrub populations typically damaged by burning (Mayeux et al. 1991).

During the past half-century, many noxious broadleaf species have expanded their range in the western United States. Although this can be associated with soil disturbance by human activities, it is also caused by livestock selecting and overgrazing the annual grasses. Broadleaf species such as Isatis tinctoria, Centaurea spp., and Cirsium spp. tend to be avoided by livestock. This can favor a rapid shift in the dominant species within these plant communities (Callihan and Evans 1991). In many cases, these broadleaf species produce an extensive taproot system that can extract more moisture from deep within the soil profile. Thus, they remain green longer into the dry season than do the annual grasses. In addition, these invasive broadleaf species typically produce large numbers of seeds (Roché et al. 1994).

Table 2. Distribution of major rangeland_weeds.

\begin{tabular}{llc}
\hline \multicolumn{1}{c}{ Species } & \multicolumn{1}{c}{ Common name } & Estimated ha infested \\
\hline Centaurea maculosa & spotted knapweed & $2,900,000$ \\
Centaurea diffusa & diffuse knapweed & $1,300,000$ \\
Centaurea solstitialis & yellow starthistle & $8,000,000$ \\
Bromus tectorum & downy brome & $40,000,000$ \\
Euphorbia esula & leafy spurge & $1,100,000$ \\
\hline
\end{tabular}

Page 4 of 21 


\section{Impact of noxious range weeds}

Rangeland weeds can have a significant impact on both humans and the environment. Their impact on human activities can be associated with livestock production, including interfering with grazing practices, lowering yield and quality of forage, increasing costs of managing and producing livestock, slowing animal weight gain, reducing the quality of meat, milk, wool, and hides, and poisoning livestock. In addition, infestations can reduce recreational land values and the spiny species can cause human health problems.

Noxious weeds cause more economic loss in rangeland than all other pests combined (Quimby et al. 1991). Bovey (1987) estimated the financial impact of rangeland weeds to be $\$ 2$ billion annually. E esula and Centaurea spp. infestations can reduce grazing capacity by more than $50 \%$ (Olson 1999a). For example, cattle will avoid grazing areas even lightly infested with $E$ esula. In Montana, North Dakota, South Dakota, and Wyoming, the total direct and secondary annual economic impact of $E$ esula on the livestock industry was estimated in 1993 to exceed $\$ 129$ million (Leitch et al. 1996). Hirsch and Leitch (1996) also estimated a $\$ 42$ million annual loss due to three Centaurea species in Montana.

Poisonous range plants also have had a significant financial impact on the livestock industry. Direct losses due to poisoning of cattle and sheep in 1988 were estimated at $\$ 169$ million with an additional $\$ 65$ million in indirect losses associated with reduced reproduction and growth rates and lower quality milk or wool (Frandsen and Boe 1991). In 1989, estimates of the total loss increased to $\$ 340$ million.

Ascribing a monetary value to the impact of noxious rangeland weeds on environmental aspects unrelated to human activity is difficult. However, weed infestations can reduce plant diversity, threaten rare and endangered species, reduce wildlife habitat and forage, alter fire frequency, increase erosion, and deplete soil moisture and nutrient levels.

Several noxious range weeds have been shown to reduce species richness, plant diversity, and community productivity in a number of areas (Belcher and Wilson 1989; Parmenter and MacMahon 1983; Rikard and Cline 1980; Wallace et al. 1992). For example, Belcher and Wilson (1989) reported a significant reduction in the five most common native species in an E. esula-infested mixed-grass prairie. In addition, they found most native species were absent where E. esula was most abundant, and species richness declined by nearly $75 \%$ from the margin to the center of the infestation. Following management efforts, plant diversity often increases. For example, the number of plant species present in California rangelands increased by $35 \%$ following biological control of $\mathrm{Hy}$ pericum perforatum (DeLoach 1991). Rare plants are particularly vulnerable to noxious weed infestations (Rosentreter 1994). In Montana, C. maculosa reduced seed germination and seedling establishment of a rare endemic forb, Arabis fecunda (Lesica and Shelly 1996).

Loss in structural diversity can cause ecosystem instability, and the introduction of some species can increase fire frequency (Rosentreter 1994; Whisenant 1990). This is particularly true in B. tectorum-infested rangeland. Even in tropical areas of Hawaii the invasion of non-native warm, and cool-season grasses has provided an abundance of fine

Page 5 of 21 
fuels and increased fire frequencies (D'Antonio and Vitousek 1992). This has subsequently led to dominance by more fire-tolerant non-native species.

Noxious weed invasions in rangeland can also impact wildlife habitat and forage. In C maculosa-infested range, Cervus elaphus nelsoni (Rocky Mountain elk) use was reduced by $98 \%$ compared with bunchgrass-dominated sites (Sheley et al. 1998). By comparison, when $C$. maculosa was removed from a historic elk winter range in western Montana, elk use increased dramatically (Thompson 1996). E. esula also has been shown to significantly impact forage value for Bos bison (bison), Odocoileus spp. (deer), and elk in Theodore Roosevelt National Park in North Dakota (Trammell and Butler 1995). Bison and deer use of E. esula-infested areas was 83 and $70 \%$ less than noninfested sites, respectively.

Many noxious range weeds, particularly broadleaf species, have deep taproot systems and very little surface foliage compared with annual grasses and perennial bunchgrasses. As a result, surface water runoff and stream sediment yields were 56 and 192\% higher, respectively, in a C. maculosa dominated site compared with adjacent native perennial grassland (Lacey et al. 1989). In addition, water infiltration rates were reduced where $C$. maculosa dominated. The deep root systems of noxious weeds allow the plants to actively grow later in the summer compared with native bunchgrasses and forbs. This can influence soil moisture and nutrient availability in the following growing season (Gerlach and Rice 1996). Because the roots of noxious weeds are deeper than native grasses, they also contribute less organic matter near the soil surface (Olson 1999a).

\section{Noxious range weed management}

\section{Control options}

\section{Mechanical Control}

A number of mechanical techniques are used to control rangeland weeds including hand-pulling, hoeing, tilling, mowing, grubbing, chaining, and bulldozing. Hand-pulling and hoeing or shoveling are effective methods in loose and moist soil with shallowrooted weeds that are killed with complete crown removal (Sheley et al. 1999a). These techniques are also effective for the control of small infestations or weeds at the fringe of a major infestation. They also are commonly used in a follow-up management program where only a few plants remain (Sheley et al.1998).

Mowing is also a commonly used tool for control of noxious range annuals and some perennials (Benefield et al. 1999; Tyser and Key 1988). It can prevent seed production, reduce carbohydrate reserves, and give advantages to desirable perennial grasses. The success of mowing often depends on timing and, in the case of $C$. solstitialis (Benefield et al. 1999), the basal branching pattern of the plants. Mowing will not control C. solstitialis plants that have profuse basal branching, even with multiple cuttings. The optimum time for mowing most annual species is in the flowering stage before seed development. Used improperly or with the wrong species, mowing can promote a noxious weed problem. For example, when soil moisture is adequate or replenished, $C$. diffusa produce's more seeds after mowing than without mowing (Sheley et al. 1999a). 
Tillage practices also can control annual species, but in perennial species rarely provide control and can often lead to the spread of weeds such as C. maculosa or Lepidium latifolium (Young et al. 1998). There are some notable exceptions, however. For example, Lym and Messersmith (1993) successfully controlled E esula with two cultivations each autumn over a three-year period. While tillage can be used in level areas, it is not a practical tool for weed control in most rangeland terrain.

For control of shrubs or trees, mechanical methods can include chaining, bulldozing, roller chopping, wood-cutting, root-plowing (power-grubbing), and shredding (Cross and Wiedemann 1985; McHenry and Murphy 1985; Rasmussen 1991). Most of these mechanical treatments require relatively gentle terrain. Chaining, bulldozing, and fuel-wood cutting are generally effective only for large shrubs or trees that do not readily resprout from the roots, while shredding can only be used on smaller shrubs (Cross and Wiedemann 1985). Bulldozers can be used to remove tree stumps that are capable of resprouting (McHenry and Murphy 1985).

\section{Cultural control}

Proper grazing management can minimize spread and effectively manage noxious weeds in rangeland. Olson (1999b) describes three grazing strategies for managing weeds: (1) moderate grazing levels to minimize the physiological impact on native plants and to reduce soil disturbance; (2) intensive grazing to counteract inherent dietary preferences of cattle, resulting in equal impacts on all forage species including weeds; and (3) multispecies grazing that distributes the impact of livestock grazing more uniformly among desirable and undesirable species. Multispecies grazing takes advantage of the inherent grazing preferences among different classes of livestock (Walker 1994). In all cases, it is important to select the most appropriate grazer for the specific situation.

Moderate grazing can take advantage of an animal's dietary preference. Inherent diet preferences among livestock species can be a major force in shifting species composition of native plant communities (Bowns and Bagley 1986). For example, Capra spp. (goats) prefer E esula as a dietary constituent compared with cattle (Kirby et al. 1997; Landgraf et al. 1984; Walker et al. 1994). This can shift a plant community toward more desirable and perhaps competitive grass species (Sheley et al. 1999a). In contrast, cattle avoid grazing areas infested with E. esula (Lym and Kirby 1987), thus increasing the infestation levels. Preferential grazing also can be used to manage poisonous plants. Senecio jacobaea contains pyrrolizidine alkaloids that are highly toxic to cattle and horses (Kingsbury 1964). Sheep, however, can graze the weed with no ill effects. Grazing sheep in heavily infested S. jacobaea pastures has been successful in western Oregon (Coombs et al. 1991). In contrast, cattle can use areas not suited for sheep, such as Hymenoxys spp., Helenium spp., B. tectorum, and Taeniatherum caput-medusae ranges (Quimby et al. 1991).

Foraging behavior can also influence the effectiveness of a particular livestock class. Cattle and goats dramatically reduced $C$ solstitialis infestations when the plants were grazed at the rosette or pre-spiny stage. However, cattle tend to avoid $C$ solstitialis once the buds produce spines, whereas goats continue to browse $C$ solstitialis even in the flowering stage (Thomsen et al. 1993).

Page 7 of 21 
Timing also can be critical to the success of grazing. The ideal time to graze is when the noxious species is most susceptible to defoliation or when the impact on the desirable vegetation is minimal (Kennett et al. 1992). Sheep grazing $C$ maculosa when the associated grasses were dormant altered the age class distribution and reduced seed production of the weed (Sheley et al. 1998).

As an alternative to moderate grazing pressure, intensive time-controlled grazing will minimize the grazers' ability to avoid less palatable noxious weed species. High stocking rates may force cattle to graze typically less preferable species, particularly noxious weeds. This should result in a more uniform composition of range plant species and more balanced competitive relationships among native and nonindigenous species (Olson 1999b). Intensive grazing for a few days, practiced on a rotational basis, is a management system widely adopted in other countries (DiTomaso 2000).

Historically, fire has played an important role in the maintenance of many ecosystems, particularly grasslands (Hatch et al. 1991). In rangeland, prescribed burning is often used for long-term suppression of woody species, including A. tridentata, Ericameria austrotexana, and Juniperus spp. (Bunting 1994; Mayeux and Hamilton 1988; Senft 1983). However, burning has also been used to successfully control non-woody species including Opuntia spp. (Ueckert et al. 1988) and annual species such as T caput-medusae (George 1992) and C. solstitialis (DiTomaso et al. 1999a). The timing of a prescribed burn is critical to successfully control the weed. Burns should be conducted following seed dispersal and senescence of desirable grasses and forbs and before viable seed production by the noxious weed. Prescribed burning in rangeland also can stimulate annual and perennial grass growth (DiTomaso et al. 1999a; Sheley et al. 1999a) and enhance native forb diversity (DiTomaso et al. 1999a). However, it is important to note that fire may promote colonization by many weeds or rapid recovery of noxious perennial species such as L. latifolium, Tamarix spp., or E esula (Lacey et al. 1992). In addition, infestations of invasive annual grasses such as B. tectorum may increase following burning (Young and Evans 1978).

The goal of rangeland management should be to improve degraded rangeland communities and make them less susceptible to noxious weed invasion and spread. Revegetation with desirable.and competitive plant species is the best long-term sustainable method of suppressing weed invasions, establishment, or dominance, while providing high forage production (Borman et al. 1991; Lym and Tober 1997). Revegetation can be accomplished by broadcast-seeding or interseeding forage grasses or legumes into existing communities (Volesky et al. 1990) or by drill-seeding into plowed, disked, herbicidetreated, or no-till rangeland (Jacobs et al. 1999). The success of drill-seeding programs is greater than those using broadcast-seeding techniques.

The choice of species used in a revegetation effort is critical to its success. Seeded species need to be adapted to the soil conditions, elevation, climate, and precipitation level of the site (Jacobs et al. 1999). Choice of species that best fit the intended use of the site is also important. For example, if livestock grazing is the primary objective of a revegetation program, a perennial grass with high forage production may be the appropriate choice (Jacobs et al. 1999).

Page 8 of 21 
In a revegetation program designed to suppress noxious weeds, a major limitation is choosing a species more vigorous than the invasive weed. Only a limited number of species have proven to be aggressive enough to displace invasive species. The proper species choice varies depending on the location and objective. Perennial bunchgrasses are among the most commonly used for revegetating western rangelands. For example, Agropyron cristatum decreased the rate of vegetative spread, limited density, reduced seed production, and suppressed topgrowth of E esula in Saskatchewan (Selleck et al. 1962). In Wyoming, revegetation with Psathyrostachys juncea and Elytrigia intermedia var. trichophorum cultivar 'Luna' significantly reduced $E$ esula infestations (Ferrell et al. 1993). Agropyron desertorum and Elytrigia intermedia ssp. intermedia were effective for E esula control in Montana (Wallander and Olson 1995), E intermedia ssp. intermedia and $E$ intermedia var. trichophorum were best in North Dakota (Lym and Tober 1997), and Schizachyrium scoparium was most effective in Minnesota (Biesboer et al. 1994). In Oregon, Festuca ovina L. and Dactylis glomerata L., but not A. desertorum, provided long-term suppression of $C$. diffusa (Larson and McInnis 1989). Broadleaf species can also be used in revegetation programs to suppress rangeland weeds. Lee (1986) showed that Trifolium subterraneum L. forms a dense canopy that prevents Chondrilla juncea encroachment.

Though perennial grasses have been shown to be most successful in competing with rangeland weeds, using a combination of species with various growth forms when designing seed mixes is best. For example, seed mixtures of grasses with legumes improved the rate of microbial and soil structure recovery compared with grasses alone (Jacobs et al. 1999). Using seed mixtures, however, may limit the control option for noxious weed control. Thus, a revegetation program may require initial seeding with perennial grasses during the weed management phase followed by subsequent reseeding with broadleaf species. Under this condition, revegetation programs may require several years to be successful.

In any revegetation program using non-native species, ensuring that an introduced species will not itself become invasive is important. For example, Phalaris aquatica L. is a perennial bunchgrass native to the Mediterranean region. It was planted commonly as a high-value pasture forage, but has escaped to colonize wildlands and displace native species (Harrington and Lanini 2000).

\section{Biological control}

The goal of a biological control program is not to eradicate the target weed, but to exert sufficient environmental stress to reduce its dominance in the plant community (Wilson and McCaffrey 1999). Insect agents can achieve this by boring into roots, shoots, and stems, defoliation, seed predation, or extracting plant fluids. All these effects can reduce the competitive ability of the plant relative to the surrounding vegetation. Over the past 100 years, more than 200 control agents have been released against 114 weed species worldwide (Blossey et al. 1994). Of these, 165 have been imported and released in the continental United States and Canada (Goeden 1993). Although biological control agents can include nematodes, pathogens, and vertebrates, 114 of the 165 released organisms are arthropods (insects and mites) (Julien 1989). The vast majority of released agents for terrestrial weeds are targeted for nonindigenous weeds of rangeland (Julien 1992). Despite the many attempts to control rangeland weeds through biological control, most attempts 
have been unsuccessful. Of the 23 weed species where biological control has been attempted, only $29 \%$ have demonstrated complete or significant levels of control in large areas (DeLoach 1991). Where it is successful, however, biological control can be a costeffective, long-term, and self-sustaining management option (Blossey et al. 1994).

In the United States, the success of the $H$. perforatum biological control program led to the development of many other control programs. For example, the biological control of $S$. jacobaea in rangelands of western Oregon has led to a $90 \%$ reduction in weed densities, primarily because of the activity of Longitarsus jacobaeae (ragwort flea beetle) (McEvoy et al. 1991). In other cases such as C. maculosa (Sheley et al. 1998) and C. solstitialis (Balciunas and Villegas 1999), the agents do not reduce the population of the weed dramatically, but they significantly reduce seed production. Over time, this may shift the competitive balance to associated species, particularly when biological control is integrated with other control methods.

\section{Chemical control}

Herbicides are the primary method of weed control in most rangeland systems. Of the 400 million ha of rangeland in the United States, about 25\% were treated with herbicides in 1997 (Bussan and Dyer 1999). Herbicides can be applied to rangeland by a number of methods including fixed-wing aircraft, helicopter, ground applicators, backpack sprayers, and rope wick applicators.

Herbicides commonly used in rangelands of the western United States are listed in Table 3. Of these, the auxin or growth regulator herbicides have played the most important role in rangeland weed control. These compounds include picloram, 2,4-D, dicamba, triclopyr, and clopyralid.

Table 3. Commonly used rangeland herbicides (from Bussan and Dyer 1999).

\begin{tabular}{|c|c|c|c|c|}
\hline $\begin{array}{c}\text { Common } \\
\text { name }\end{array}$ & Trade name & Mode of action & Weed spectrum & Soil residual \\
\hline $2,4-\mathrm{D}$ & Many trade names & Growth regulator & Broadleaf species & No \\
\hline Clopyralid & Transline $®$ & Growth regulator & Broadleaf species & Yes \\
\hline Dicamba & Banvel®, Vanguish & Growth regulator & Broadleaf species & No \\
\hline Glyphosate & Roundup ${ }^{\circledR}$ & Amino acid synthesis inhibitor & Non-selective & No \\
\hline Imazapyr & Arsenal $®$, Stalker $®$ & Amino acid synthesis inhibitor & Non-selective & Yes \\
\hline Metsulfuron & Escort $®$ & Amino acid synthesis inhibitor & Broadleaf species & Yes \\
\hline Picloram & Tordon $®$ & Growth regulator & Broadleaf species & Yes \\
\hline Tebuthiuron & Spike ${ }^{\circledR}$ & Photosynthetic inhibitor & Non-selective & Yes \\
\hline Triclopyr & Garlon $®$, Remedy® & Growth regulator & Broadleaf species & No \\
\hline
\end{tabular}

Timing of herbicide applications can determine the effectiveness of the treatment. Although most perennials and shrubs are easier to control with an autumn herbicide application, the most effective timing for E esula control is in spring (Lym. and Messersmith 1994). Timing may also vary depending on the herbicide. Control of L. latifolium and Cardaria draba with sulfonylurea herbicides was effective with applications made in spring, summer, or autumn (Drake and Whitson 1989; Whitson et al. 1989; Young et al. 1998), whereas control with a postemergence herbicide such as glyphosate was best when 
applied in spring when plants were at the late-bud to early-flowering stage (Waterhouse and Mahoney 1983; Young et al. 1998). With annual species such as C. solstitialis, application of postemergence herbicides in spring does not provide full season control, but spring treatment with picloram or clopyralid gives excellent season-long control and maximizes forage production (DiTomaso et al. 1999b).

Although herbicides effectively control noxious range weeds, they seldom provide long-term control of weeds when used alone (Bussan and Dyer 1999). In the absence of a healthy plant community composed of desirable species, one noxious weed may be replaced by another equally undesirable species insensitive to the herbicide treatment. In addition, continuous use of a single herbicide can select for resistance in the target weed species. Population shifts through repeated use of a single herbicide may also reduce plant diversity and cause nutrient changes that decrease the total vigor of the range. Thus, herbicide use in rangelands should be part of an integrated weed management system.

\section{Integrated approaches}

Most often a single method is not effective to achieve sustainable control of a range weed. A successful long-term management program should be designed to include combinations of mechanical, cultural, biological, and chemical control techniques. This is particularly true in revegetation programs where seedling establishment is the most critical stage and is dependent upon the suppression of competitive species, especially annual grasses and broadleaf species such as C. solstitialis (Jacobs et al. 1999; James 1992).

Table 4. Successful examples of integrated strategies for control of rangeland weeds.

\begin{tabular}{lll}
\hline Weed species & Techniques employed & Citation \\
\hline Euphorbia esula & Herbicide and biocontrol & Lym et al. 1996, Nelson et al. 1998 \\
& Herbicide and revegetation & Ferrell et al. 1998, Selleck et al. \\
& Tillage and herbicide & 1962, Masters and Nissen 1998 \\
& Tillage and fertilization & Lym and Messersmith 1993 \\
& Grazing and biocontrol & Lym and Messersmith 1993 \\
& Grazing and herbicide & Hansen 1993 \\
Centaurea solstitialis & Herbicide, burning, and revegetation & Lym et al. 1997 \\
Centaurea spp. & Herbicide, revegetation, and biocontrol & Masters and Nissen 1998 \\
& Mowing and herbicide & Renz and DiTomaso 1999 1999 \\
Bromus tectorum & Tillage, herbicide and revegetation & Bottoms and Whitson 1998 \\
& Burning and herbicide & Lacey et al. 1995 \\
Taeniatherum & Herbicide and revegetation & Whitson and Kock 1998 \\
caput-medusae & Tillage and revegetation & Whitson and Kock 1998 \\
Chondrilla juncea & Herbicide and grazing & Whitson and Kock 1998 \\
\hline
\end{tabular}

Numerous integrated approaches have been developed for the management of E esula (Table 4). These include the judicious use of herbicides in combination with biological control agents (Lym et al. 1996; Nelson et al. 1998) or grazing (Lym et al. 1997). Other 
successful combinations for E. esula control include herbicide and perennial grass revegetation (Ferrell et al. 1998; Masters and Nissen 1998; Selleck et al. 1962), sheep grazing and biological control insects (Hansen 1993), goat grazing and herbicides (Lym 1998), tillage followed by a herbicide or fertilization (Lym and Messersmith 1993), and an autumn herbicide application followed by a spring prescribed burn and revegetation with perennial grasses (Masters and Nissen 1998).

Other integrated approaches have been used successfully in rangeland to manage $B$. tectorum, T caput-medusae, Centaurea spp., C juncea, and L. latifolium (Table 4).

\section{Developing and implementing a rangeland noxious weed management strategy}

\section{Prevention}

About $10 \%$ of federally owned lands are infested with invasive weeds (Asher, personal communication). However, much of the currently uninfested rangelands have the potential to be invaded by noxious weed species. Consequently, preventing the introduction of rangeland weeds is the most cost-effective method for their management and is an essential component of a noxious weed management strategy. The major elements of a prevention program are to stop introduction of noxious weed seeds or vegetative reproductive fragments, reduce the susceptibility of the ecosystem to invasive weed establishment, develop effective education materials and activities, and establish a program for early detection and monitoring.

\section{Avenues of introduction}

Weeds can encroach by establishing small infestations in relatively close proximity to a larger infestation (Sheley et al. 1999a). This can be through natural means including wind, water, and animal dispersal mechanisms. To prevent this type of encroachment, neighboring weed infestations on adjacent lands should be contained. The most effective method of containment is to spray the borders of infested areas with a herbicide (Sheley et al. 1999b).

In many cases, however, introduction of noxious weeds on rangelands can be associated with human-related activities. Seeds or plant vegetative fragments can be introduced as contaminants of hay or animal feed. This can be prevented by using feed that is certified as weed-free (Sheley et al. 1999b). Noxious weeds can also be introduced as contaminants of perennial grass, wildflower, or crop seed. Seed purchased or collected for use in revegetation programs should be examined to ensure its purity. Transporting soil contaminated with noxious weed propagules can lead to new infestations. This is a common method of introducing noxious weeds along roadsides or in construction sites.

Livestock can move range weeds from one area to another by passing viable seed through their digestive system or by transporting seed attached to hair. For example, the intact inflorescence of Centaurea squarrosa is readily dispersed by clinging to the wool of sheep (Roché and Roché 1989). Seed dispersal by animals can be minimized by avoiding livestock grazing in weed-infested areas during flowering and seeding stages or by 
holding animals for seven days before moving them to uninfested areas (Sheley et al. 1998).

Equipment and vehicles driven through infested land can transport noxious weed seed or fragments to uninfested areas. Even human clothing can transport noxious weed seed, particular in soil particles attached to shoes and boots. Equipment and clothing should be cleaned immediately after leaving an infested site.

It is particularly important to control or prevent weed invasions along transportation corridors, including roadsides, waterways, and railways. These areas are typically disturbed sites and, consequently, are more susceptible to noxious weed establishment (Forcella and Harvey 1983; Tyser and Key 1988).

\section{Susceptible landscapes}

Invasive weeds often become established following disturbances, including mechanical disruption or fire. Although many weeds are capable of invading well-managed undisturbed areas, disturbance allows rapid establishment and spread of many noxious range species. The greater the disturbance, the more likely that an invasive weed will occupy all available niches and form a monotypic stand (Sheley et al. 1998). Following soil disturbance, sites should be monitored to prevent establishment and subsequent seed production in susceptible areas. In many cases, disturbed sites should be revegetated with desirable species to slow the invasion of noxious weeds.

Proper grazing can maintain desired plants and provide a more competitive environment. To minimize weed invasions, overgrazing is discouraged and grazed plants should be allowed to recover before regrazing (Sheley et al. 1998). This ensures that grasses remain healthy and vigorous, maximizing their competitiveness and reducing the potential for noxious weed encroachment (Sheley et al. 1999b). Revegetation with aggressive perennial grasses can prevent establishment of noxious range species (Sheley et al. 1998). However, communities most resistant to weed infestations usually are composed of a diversity of plant species. This diversity allows maximum niche occupation and resource capture (Sheley et al. 1999a).

\section{Educational programs}

Employees and the public can be educated about weeds through a number of methods. Information can be made available through brochures, posters, internet websites, calendars, scientific papers, and other written media. Educational programs can be conducted for landowners, land managers, or the general public. These can include public seminars, professional symposia, school programs, and volunteer field workshops conducted by church groups, environmental organizations, scouts, and other groups. The media also play an important role in educating the public through radio or television news stories, public service announcements, newspaper articles, public displays, or even roadside bulletin boards. All these educational events or activities facilitate greater cooperation among private, federal, state, and county agencies, industries, landowners, and the general public. In addition, they increase the potential for early detection and rapid response to new infestations.

\section{Early detection and monitoring}

The best management of rangeland weeds is to recognize potential weed problems early, control weeds before they reproduce and spread, and monitor sites regularly to 
maintain adequate follow-up control. Effective early detection efforts depend upon proper training of land managers, pest management professionals, and property owners (Zamora and Thill 1999). Understanding the potential threats that may exist on surrounding property can provide an early warning system for weed invasion. One successful method for preventing the invasion of weeds is to regularly inventory the area by field surveys or aerial photography and remove individual weed plants before they become well established (Sheley et al. 1999b).

\section{Eradication}

An effective eradication program is closely tied to prevention. The key element to a successful eradication plan is early recognition and rapid response to prevent reproduction and the development of a seedbank. Control options in an eradication program are typically limited to mechanical removal and herbicide treatment. The objective is to completely eliminate the species from that site, not to manage the population. Eradication is not complete until all viable propagules of the weed are depleted from the soil (Zamora and Thill 1999). This can be a difficult task when target plants have deep vegetative reproductive structures or an extended seed dormancy.

Eradication efforts are usually confined to smaller infestations $(<1 \mathrm{ha})$. These can be satellite populations adjacent to large infestations or isolated invasions far from other infestations. In some cases, eradication efforts can focus on the borders of large infestations (Zamora and Thill 1999). An eradication plan can be developed for small $(<5$ ha) or large ( $>50 \mathrm{ha}$ ) infestations. Financial resources, available technology, potential benefits, and social and geographical constraints will limit the size of the infested area that can be targeted for weed eradication (Zamora and Thill 1999). In some cases, large eradication programs require revegetation to completely eliminate a remnant noxious weed population. Even when all these issues are considered, complete eradication of large infestations is rare.

\section{Developing a rangeland noxious weed management strategy}

Once a weed is well established, it is unlikely that eradication can be accomplished without extremely high financial and labor inputs. The ultimate objective under these circumstances is to manage the infested area and contain the large-scale infestation. However, the goal of any management plan should not simply be control of the noxious weed(s), but improvement of the degraded rangeland community, enhanced utility of the ecosystem, and prevention of reinvasion or invasion by other noxious weed species. When rangeland deterioration is severe and desirable species are either absent or scarce, reclaiming the productive potential of degraded rangeland through the reintroduction of desirable plant mixtures is necessary (Masters and Nissen 1998).

The ultimate goal of any rangeland management program should be to develop a healthy, weed-resistant plant community that consists of a diverse group of species that occupy most of the niches. Thus, an ecologically based management strategy should achieve the desired land-use objectives such as forage production, wildlife habitat development, or recreational land maintenance (Jacobs et al. 1999; Sheley et al. 1998). To ac- 
complish these objectives, land managers will require an understanding of the goals, limitations, and biology of the management system.

Understanding the goals of a weed management system is critical to determining the proper management approach, Management strategies will differ if the primary goal is to enhance forage quantity and quality for livestock and wildlife, restore native vegetation or endangered species, or increase recreational value. In addition, selection of the proper management tool(s) and program may depend on a number of factors including weed species, effectiveness of the control techniques, availability of control agents or grazing animals, length of time required for control, environmental considerations, chemical use restrictions, topography, climatic conditions, and relative cost of the control techniques (Sheley et al. 1999a).

One of the most important aspects of developing a noxious weed management strategy is to identify accurately and delineate lands infested with the weed(s) (Sheley et al. 1998). Knowing where the infestations occur can determine the control method used, assist in prioritizing the management strategy, and identify areas where eradication, containment, or management can be achieved. In addition, this information can prevent unnecessary herbicide treatments and slow the spread of the weed.

Weed infestations should be identified on a map and records should contain weed species present, areas infested, weed density, rangeland under threat of invasion, soil and range types, and other site factors pertinent to successful management of noxious weedinfested rangeland (Sheley et al. 1998). Ideally, three surveys should be conducted each year: a spring survey to detect weeds early enough to allow effective chemical control, a second survey in early summer, and the last survey in early autumn (Sheley et al. 1999b). Continual monitoring is necessary to prevent reinvading populations from becoming established. if possible, developing a predictive model will allow easier identification of invaded sites and reduce search time for new invasions (Johnson 1999).

A thorough understanding of the biology and ecology of invasive weeds, as well as their ecosystems, is necessary for their long-term management. This includes an understanding of invasion dynamics associated with reproduction, growth, spread, resource use, soil conditions favoring growth, and competitive interactions with other species. In addition to understanding the biology and ecology of the weed, it is important to be familiar with characteristics of the ecosystem. This can include an awareness of other desirable and weedy species present, the potential for invasion into other yet uninfested sites within the area, impact of the management strategy on sensitive species and habitats, soil conditions and range types present, as well as other ecosystem parameters.

A coordinated effort among interested parties, including the general public, private and public landowners, federal, state, and county agencies, and environmental organizations can lead to a more effective management plan. A cooperative program can eliminate duplication of effort, reduce avenues for reintroduction, consolidate equipment and labor costs, and decrease the risk of repeating previous failures. In addition, coordinated management teams can obtain cost-sharing grants to manage large infestations more effectively. 


\section{Implementing a strategic plan}

Implementing a strategic plan is the most critical aspect of noxious weed management and typically requires input from weed management experts. Before any option can be employed, financial considerations must be addressed and a budget must be prepared to keep project costs within reasonable limits (Whitson 1998). Limited funding may require prioritizing areas of greatest concern. For example, the decision to revegetate must consider direct costs (seedbed preparation, seeds and seeding, follow-up management), indirect costs (risk of failure, non-use during establishment period), and benefits (increased forage, improved ecosystem function, soil conservation) (Jacobs et al. 1999).

Whenever possible, control options in the strategic plan should integrate mechanical, cultural, biological, and chemical techniques. A long-term commitment of three to many years will be necessary in nearly all cases to deplete the weed seedbank. Regardless of the approach employed, range monitoring and annual evaluations should be conducted to determine the adequacy of the management plan (Sheley et al. 1999b). Changes in management approaches may be necessary to adjust to any unforeseen problems and improve effectiveness.

Once the desired objectives have been attained, a yearly follow-up program will be necessary to prevent reinfestation. This may involve annual spot herbicide treatments, periodic burning or broadcast herbicide applications, or overseeding of desirable species at specific intervals. In addition, changes in grazing practices may be required to ensure that rangeland conditions do not become susceptible to rapid reinfestation.

\section{Literature cited}

Balciunas, J. and B. Villegas. 1999. Two new seed head flies attack yellow starthistle. California Ag. 53(2):8-11.

Belcher, J. W, and S. D. Wilson. 1989. Leafy spurge and species composition of a mixed-grass prairie. J. Range Manage. 42:172-175.

Benefield, C. B., J. M. DiTomaso, G. B. Kyser, S. B. Orloff, K. R. Churches, D. B. Marcum, and G. A. Nader. 1999. Success of mowing to control yellow starthistle depends on timing and plant's branching form. California Ag. 53(2):17-21.

Biesboer, D. D., B. Darveaux, and W. L. Koukkari. 1994. Controlling leafy spurge and Canada thistle by competitive species. St. Paul, MN: Minnesota Dept. Transportion, Office of Res. Admin. Publ. No. 78. $1 \mathrm{p}$.

Billings, W. D. 1994. Ecological affects of cheatgrass and resultant fire on ecosystems in the western Great Basin. Pages 22-30 in S. B. Monsen and S. G. Kitchen, eds. Proceedings of Ecology and Management of Annual Rangelands. Ogden, UT. USDA Forest Service Intermountain Research Station Gen. Tech. Rep. INT-GTR-313.

Blossey, B., D. Schroeder, S. D. Hight, and R. A. Malecki. 1994. Host specificity and environmental affect of the weevil Hylobius transversovittatus, a biological control agent of purple loosestrife (Lythrum salicaria). Weed Sci. 42:128-133.

Borman, M. M., W. C. Krueger, and D. E. Johnson. 1991. Effects of established perennial grasses on yields of associated annual weeds. J. Range Manage. 44:318-326. 
Bottoms, R. M. and T. D. Whitson. 1998. A systems approach for the management of Russian knapweed (Centaurea repens). Weed Technol. 12:363-366.

Bovey, R. W, 1987. Weed control problems, approaches, and opportunities in rangeland. Rev. Weed Sci. 3:57-91.

Bowns, J. E. and C. F. Bagley. 1986. Vegetation responses to long-term sheep grazing on mountain ranges. J. Range Manage. 39:431-434.

Bunting, S. C. 1994. Effects of fire on juniper woodland ecosystems in the Great Basin. Pages 53-55 in S. B. Monsen and S. G. Kitchen, eds. Proceedings of Ecology and Management of Annual Rangelands. Ogden, UT. USDA Forest Service Intermountain Research Station Gen. Tech. Rep. INT-GTR-313.

Bussan, A. J. and W E. Dyer. 1999. Herbicides and rangeland. Pages 116-132 in R. L. Sheley and J. K. Petroff, eds. Biology and Management of Noxious Rangeland Weeds. Corvallis, OR: Oregon State University Press.

Callihan, R. H. and J. 0. Evans. 1991. Weed dynamics on rangeland. Pages 55-61 in L. R James, J. O. Evans, M. H. Ralphs, and R. D. Child, eds. Noxious Range Weeds. San Francisco: Westview Press.

Coombs, E. M., T. E. Bedell, and R. B. McEvoy. 1991. Tansy ragwort (Senecio jacobaea): importance, distribution, and control in Oregon. Pages 419-437 in L. F. James, J. O. Evans, M. H. Ralphs, and R. D. Child, eds. Noxious Range Weeds. San Francisco: Westview Press.

Cross, B. T., and H. T Wiedemann. 1985. Grubbing for control of blackbrush acacia (Acacia rigidula) invading rootplowed rangeland. Weed Sci. 33:263-266.

D'Antonio, C. M. and R M. Vitousek.1992. Biological invasions by exotic grasses, the grass/fire cycle, and global change. Annu. Rev. Ecol. Syst. 23:63-87.

DeLoach, C. J. 1991. Past successes and current prospects in biological control of weeds in the United States and Canada. Natural Areas J. 11:129-142.

DiTomaso, J. M. 2000. Irrigated pastures. In F. Colbert, ed. Principles of Weed Control in California, 3rd ed. Fresno, CA: Thomson Publishing. In press.

DiTomaso, J. M., G. B. Kyser, and M. S. Hastings. 1999a. Prescribed burning for control of yellow starthistle (Centaurea solstitialis) and enhanced native plant diversity. Weed Sci. 47:233-242.

DiTomaso, J. M., G. B. Kyser, S. B. Orloff, S. F. Enloe, and G. A. Nader. 1999b. New growth regulator herbicide provides excellent control of yellow starthistle. California Ag. 53(2):12-16.

Drake, K. R. and T. D. Whitson. 1989. Control of hoary cress (Cardaria draba (L.) Desv.) on pastures. Page 40 in Proceedings of the Western Society of Weed Science. Vol. 42. Western Society of Weed Science.

Enloe, S. and J. DiTomaso. 1999. Integrated management of yellow starthistle on California rangeland. Pages 24-27 in Proceedings of the California Weed Science Society. Vol. 51. California Weed Science Society.

Ferrell, M. A., T. D. Whitson, D. W Koch, and A. E. Gade. 1993. Integrated control of leafy spurge (Euphorbia esula) with Bozoisky Russian wildrye (Psatbyrostachys juncea) and Luna pubescent wheatgrass (Agropyron intermedium var. trichophorum). Pages 36-38 in Proceedings of the Western Society of Weed Science. Vol. 46. Western Society of Weed Science.

Ferrell, M. A., T. D. Whitson, D. W. Koch, and A. E. Gade. 1998. Leafy spurge (Euphorbia esula) control with several grass species. Weed Technol. 12:374-380.

Forcella, F. and S. J. Harvey. 1983. Eurasian weed infestation in western Montana in relation to vegetation and disturbance. Madrono 30:102109.

Frandsen, E. and D. Boe. 1991. Economics of noxious weeds and poisonous plants. Pages 442-458 in L. F. James, J. O. Evans, M. H. Ralphs, and R. D. Child, eds. Noxious Range Weeds. San Francisco: Westview Press. 
Goeden, R. D. 1993. Arthropods for suppression of terrestrial weeds. Pages 231-237 in R. D. Lumsden and J. L. Vaughn, eds. Pest Management: Biologically Based Technologies. Washington, D.C.: American Chemical Society.

George, M. R. 1992. Ecology and management of medusahead. Davis, CA: University of California Range Sci. Rep. 32:1-3.

Gerlach, J. D. and K. Rice. 1996. Centaurea solstitialis threatens California's ecosystems. Bull. Ecol. Soc. Amer. 77:160.

Hansen, R. 1993. Effects of Aphthona flea beetles and sheep grazing in leafy spurge stands. Pages 47-48 in Proceedings of 1993 Leafy Spurge Symposium. Silvercreek, CO.

Harrington, K. C. and W. T. Lanini. 2000. Invasive plants of California's wildlands. In C. Bossard, J. M. Randall, and M. Hoshovsky, eds. Wildland Weeds of California. Berkeley, CA: UC Press. In press.

Hatch, D. A., J. W. Bartolome, and D. S. Hillyard. 1991. Testing a management strategy for restoration of California's native grasslands. Pages 343-349 in Proceedings of the Symposium on Natural Areas and Yosemite: Prospects for the Future. Denver, CO: U.S. National Park Service.

Hirsch, S. A. and J. A. Leitch. 1996. The effect of knapweed on Montana's economy. Ag. Econ. Rep. No. $355.43 \mathrm{p}$.

Horton, W H. 1991. Medusahead: Importance, distribution, and control. Pages 394-398 in L. F. James, J. O. Evans, M. H. Ralphs, and R. D. Child, eds. Noxious Range Weeds. San Francisco: Westview Press.

Jacobs, J. S., M. F. Carpinelli, and R. L. Sheley. 1999. Revegetating noxious weed-infested rangeland. Pages 133-141 in R. L. Sheley and J. K. Perroff. eds. Biology and Management of Noxious Rangeland Weeds. Corvallis, OR: Oregon State University Press.

James, D. 1992. Some principles and practices of desert revegetation seeding. Arid Lands Newsletter, 32:22-27.

Johnson, D. E. 1999. Surveying, mapping, and monitoring noxious weeds on rangelands. Pages 19-35 in R. L. Sheley and J. K. Petroff, eds. Biology and Management of Noxious Rangeland Weeds. Corvallis, OR: Oregon State University Press.

Julien, M. H. 1989. Biological control of weeds worldwide: trend, rates of success and the future. Biocontrol News Info. 10:299-306.

Julien, M. H., ed. 1992. Biological Control of Weeds: A World Catalogue of Agents and Their Target Weeds. 3rd ed. Wallingford, U.K: CAB International. $186 \mathrm{p}$.

Kennett, G. A., J. R. Lacey, C. A. Butt, K. M. Olson-Rutz, and M. R. Haferkamp. 1992. Effects of defoliation, shading and competition on spotted knapweed and bluebunch wheatgrass. J. Range Manage. 45:363-369.

Kingsbury, J. M. 1964. Poisonous Plants of the United States and Canada. Englewood Cliffs, NJ: PrenticeHall, pp. 296-397.

Kirby, D. R., I P. Hanson, and C. Hull Sieg. 1997. Diets of Angora goats grazing leafy spurge (Euphorbia esula)-infested rangeland. Weed Technol. 11:734-738.

Lacey, C. A., J. R. Lacey, P. K. Fay, J. M. Story, and D. L. Zamora. 1995. Controlling knapweed in Montana rangeland. Bozeman, MT. Montana Stare University Cooperative Extension Service Circular 311. $17 \mathrm{p}$.

Lacey, J. R., C. B. Marlow, and J. R. Lane. 1989. Influence of spotted knapweed (Centaurea maculosa) on surface runoff and sediment yield. Weed Technol. 3:627-631.

Lacey J. R., R. Wallender, and K. Olson-Rutz. 1992. Recovery, germinability, and viability of leafy spurge (Euphorbia esula) seeds ingested by sheep and goats. Weed Technol. 6:559-602.

Landgraf, B. K., R L. Fay, and K. M. Havstad. 1984. Utilization of leafy spurge (Euphorbia esula) by sheep. Weed Sci. 32:348-352.

Page 18 of 21 
Larson, L. L. and M. L. McInnis. 1989. Affect of grass seedlings on establishment and density of diffuse knapweed and yellow starthistle. Northwest Sci. 63:162-166.

Lee, G. A. 1986. Integrated control of rush skeletonweed (Chondrilla juncea) in the western U.S. Weed Sci. 34:2-6.

Leitch J. A., F. L. Leistrirz, and D. A. Bangsund. 1996. Economic effect of leafy spurge in the Upper Great Plains: Methods, models, and results. Impact Assessment 14:419-433.

Lesica, P. and J. S. Shelly. 1996. Competitive effects of Centaurea maculosa on the population dynamics of Arabis fecunda. Bull. Torrey Bot. Club. 123:111-121.

Lym, R. G. 1998. The biology and integrated management of leafy spurge (Euphorbia esula) on North Dakota rangeland. Weed Technol. 12:367-373.

Lym, R. G., R. B. Carlson, C. G. Messersmith, and D. A. Mundal. 1996. Integration of herbicides with flea beetles, Aphthona nigriscutis, for leafy spurge control. Pages 480-481 in Proceedings of the IX International Symposium on Biological Control of Weeds. Stellenbosch, South Africa.

Lym, R. G. and D. R. Kirby. 1987. Cattle foraging behavior in leafy spurge (Euphorbia esula)-infested rangeland. Weed Technol. 1:314-318.

Lym, R. G. and C. G. Messersmith. 1993. Fall cultivation and fertilization to reduce winterhardiness of leafy spurge (Euphorbia esula). Weed Sci. 41:441-A46.

Lym, R. G. and C. G. Messersmith. 1994. Leafy spurge (Euphorbia esula) control, forage production, and economic return with fall-applied herbicides. Weed Technol. 8:824-829.

Lym, R. G., K. K. Sedivec, and D. R. Kirby. 1997. Leafy spurge control with Angora goats and herbicides. J. Range Manage. 50:123-128.

Lym, R. G. and D. A. Tober. 1997. Competitive grasses for leafy spurge (Euphorbia esula) reduction. Weed Technol. 11:787-792.

Masters, R. A. and S. J. Nissen. 1998. Revegetating leafy spurge (Euphorbia esula)-infested rangeland with native tallgrasses. Weed Technol. 12:381-390.

Mayeux, H. S. and W T. Hamilton. 1988. Response of false broomweed and associated herbaceous species to fire. J. Range Manage. 41:2-6.

Mayeux, H. S., H. B. Johnson, and H. W. Polley. 1991. Pages 62-74 in L. F. James, J. O. Evans, M. H. Ralphs, and R. D. Child, eds. Noxious Range Weeds. San Francisco: Westview Press.

McEvoy, P. B., C. S. Cox, and E. M. Coombs. 1991. Successful biological control of ragwort. Ecol. App. $1: 430-432$.

McHenry, W. B. and A. H. Murphy. 1985. Weed management of California rangeland. Pages 413-423 in E. A. Kurtz and F. O. Colbert, eds. Principles of Weed Control in California. Fresno, CA: Thomson Publishing.

Morrow, L. A. and R. W. Stahlman. 1984. The history and distribution of downy brome (Bromus tectorum) in North America. Weed Sci. 32(suppl.):2-6.

Murphy, A. H. 1986. Significance of rangeland weeds for livestock management strategies. Pages 114-116 in Proceedings of the California Weed Conference.

Nelson, J. A., R. G. Lym, and C. G. Messersmith. 1998. Integration of herbicides with the biological agent Aphthona nigriscutis for leafy spurge control. Page 132 in Proceedings of the Western Society of Weed Science. Vol. 51. Western Society of Weed Science.

Olson, B. E. 1999a. Impacts of noxious weeds on ecologic and economic systems. Pages 4-18 in R. L. Sheley and J. K. Petroff, eds. Biology and Management of Noxious Rangeland Weeds. Corvallis, OR: Oregon State University Press. 
Olson, B. E. 1999b. Grazing and weeds. Pages 85-96 in R. L. Sheley and J. K. Petroff, eds. Biology and Management of Noxious Rangeland Weeds. Corvallis, OR: Oregon State University Press.

Panter, K. E. 1991. Neurotoxicity of the knapweeds (Centaurea spp.) in horses. Pages 316-324 in L. F. James, J. O. Evans, M. H. Ralphs, and R. D. Child, eds. Noxious Range Weeds. San Francisco: Westview Press.

Parmenter, R. R. and J. A. MacMahon. 1983. Factors determining the abundance and distribution of rodents in a shrub-steppe ecosystem: the role of shrubs. Oecologia 59:145-156.

Quimby, P. C., Jr., W. L. Bruckart, C. J. DeLoach, L. Knutson, and M. H. Ralphs. 1991. Biological control of rangeland weeds. Pages 84-102 in L. F. James, J. O. Evans, M. H. Ralphs, and R. D. Child, eds. Noxious Range Weeds. San Francisco: Westview Press.

Rasmussen, G. A. 1991. Oakbrush: classification, ecology, and management. Pages 352-363 in L. F. James, J. O. Evans, M. H. Ralphs, and R. D. Child, eds. Noxious Range Weeds. San Francisco: Westview Press.

Renz, M. and J. DiTomaso. 1999. Biology and control of perennial pepperweed. Pages 13-16 in Proceedings of the California Weed Science Society. Vol. 51. California Weed Science Society.

Rikard, W. H. and J. F. Cline. 1980. Cheatgrass communities: effects of plowing on species composition and productivity. Northwest Sci. 54: 216-221.

Roché, B. F., Jr., G. L. Piper, and C. J. Talbott. 1986. Knapweeds in Washington. Pullman, WA: USDA/Washington State Cooperative Extension Bull. EB1393. 41 p.

Roché, B. F., Jr., and C. T. Roché. 1991. Identification, introduction, distribution, ecology, and economics of Centaurea species. Pages 274291 in L. F. James, J. O. Evans, M. H. Ralphs, and R. D. Child, eds. Noxious Range Weeds, San Francisco: Westview Press.

Roché, B. F., Jr., C. T. Roché and R. C. Chapman. 1994. Impacts of grassland habitat on yellow starthistle (Centaurea solstitialis L.) invasion. Northwest Sci. 68:86-96.

Roché C. T. and Roché, B. F., Jr. 1989. Introductory notes on squarrose knapweed (Centaurea virgata Lam. ssp. squarrosa Gugl.) Northwest Sci. 63:246-252.

Rosentreter, R. 1994. Displacement of rare plants by exotic grasses. Pages 170-175 in S. B. Monsen and S. G. Kitchen, eds. Proceedings of Ecology and Management of Annual Rangelands. Ogden, UT: USDA Forest Service Intermountain Research Station Gen.Tech. Rep. INTGTR-313.

Selleck, G. W, R. T. Coupland, and C. Frankton. 1962. Leafy spurge in Saskatchewan. Ecol. Monogr. 32:129.

Senft, D. 1983. Fire freshens rangeland. Agric. Res. 32: 10-11.

Sheley, R. L., J. S. Jacobs, and M. E Carpinelli. 1998. Distribution, biology, and management of diffuse knapweed (Centaurea diffusa) and spotted knapweed (Centaurea maculosa). Weed Technol. 12:353362.

Sheley, R. L., S. Kedzie-Webb, and B. D. Maxwell. 1999a. Integrated weed management on rangeland. Pages 57-68 in R. L. Sheley and J. K. Petroff, eds. Biology and Management of Noxious Rangeland Weeds. Corvallis, OR: Oregon State University Press.

Sheley, R. L., M. Manoukian, and G. Marks. 1999b. Preventing noxious weed invasion. Pages 69-72 in R. L. Sheley and J. K. Petroff, eds. Biology and Management of Noxious Rangeland Weeds. Corvallis, OR: Oregon State University Press.

Thompson, M. J. 1996. Winter foraging response of elk to spotted knapweed removal. Northwest Sci. 70:10-19.

Thomsen, C. D., W. A. Williams, M. Vayssieres, F. L. Bell, and M. R. George. 1993. Controlled grazing on annual grassland decreases yellow starthistle. California Ag. 47(6):36-40. 
Trammell, M. A. and J. L. Butler. 1995. Effects of exotic plants on native ungulate use of habitat. J. Wildl. Manage. 59:808-816.

Tyser, R. W. and C. H. Key. 1988. Spotted knapweed in natural area fescue grassland: an ecological assessment. Northwest Sci. 62:151-160.

Ueckert, D. N., J. L. Petersen, R. L. Potter, J. D. Whipple, and M. W. Wagner. 1988. Managing pricklypear with herbicides and fire. Pages 10-15 in Texas Agricultural Experiment Station Report No. 4570.

Volesky, J. D., P. O. Currie, and J. R. Lacey. 1990. Comparison of two drills for interseeding rangeland. Montana Agric. Res. 7:18-22.

Walker, J. S., S. L. Kronberg, S. L. Al-Rowaily, and N. E. West. 1994. Comparison of sheep and goat preferences for leafy spurge. J. Range Manage. 47:429-434.

Walker J. W. 1994. Multispecies grazing: the ecological advantage. Pages 52-64 in Sheep Res. J. Special Issue.

Wallace, N. M., J. A. Leitch, and F. L. Leistritz. 1992. Economic impact of leafy spurge on North Dakota wildland. North Dakota Farm Res. 49:9-13.

Wallander, R. T. and B. E. Olson. 1995. Enhancing the competitiveness of other species with leafy spurge. In Proceedings of the Leafy Spurge Symposium. Fargo, ND: North Dakota State University.

Waterhouse, D. M. and J. E. Mahoney. 1983. Effect of pre-fallowing application of glyphosate on hoary cress (Cardaria draba (L.) Desv.). Australian Weeds 2:141-143.

Whisenant, S. G. 1990. Changing fire frequencies on Idaho's Snake River Plains: ecological and management implications. Pages 4-10 in E. D. McArthur, E. M. Romney, S. D. Smith, and P. T. Tueller, eds. Proceedings of the Symposium on Cheatgrass Invasion, Shrub Die-off, and Other Aspects of Shrub Biology and Management. Ogden, UT: USDA Forest Service Intermountain Research Station Gen. Tech. Rept. INT-GTR-313.

Whitson, T. D. 1998. Integrated pest management systems for weed control. Page 43 in Proceedings of the Western Society of Weed Science. Vol. 51. Western Society of Weed Science.

Whitson, T. D. and D. W. Koch. 1998. Control of downy brome (Bromus tectorum) with herbicides and perennial grass competition. Weed Technol. 12:391-396.

Whitson, T. D., A. Mooney, and M. Griswold. 1989. Control of hoary cress (Cardaria draba) with various herbicides. Page 39 in Proceedings of the Western Society of Weed Science. Vol. 42. Western Society of Weed Science.

Wilson, L. M. and J. P. McCaffrey. 1999. Biological control of noxious rangeland weeds. Pages 97-116 in R. L. Sheley and J. K. Petroff, eds. Biology and Management of Noxious Rangeland Weeds. Corvallis, OR: Oregon State University Press.

Young, J. A. and R. A. Evans. 1978. Population dynamics after wildfires in sagebrush grasslands. J. Range Manage. 31:283-289.

Young, J. A. and W S. Longland. 1996. Affect of alien plants on Grant Basin rangeland. Weed Technol. 10:384-391.

Young, J. A., D. E. Palmquist, and R. R. Blank. 1998. The ecology and control of perennial pepperweed (Lepidium latifolium L.). Weed Technol. 12:402-405.

Zamora, D. L. and D. C. Thill. 1999. Early detection and eradication of new weed infestations. Pages 73-84 in R. L. Sheley and J. K. Petroff, eds. Biology and Management of Noxious Rangeland Weeds. Corvallis, OR: Oregon State University Press. 